\title{
A Diversity of Schools: The Danish School Acts of 1814 and the Emergence of Mass Schooling in Denmark
}

\author{
Christian Larsen
}

\begin{abstract}
During the nineteenth century, national systems of mass schooling were established in western Europe. In Denmark, King Frederik VI passed a set of five schools' laws in 1814: one for the village schools, one for the market town schools, one for Copenhagen, one for the duchies of Schleswig and Holstein and one for Jews, in order to create and regulate a system of mass schooling within his realms. This study aims to analyse the impact of the 1814 School Acts and thereby, the emergence of mass schooling in Denmark in the nineteenth century. Three aspects of the 1814 Acts are analysed in this article: firstly, how a local school administration was established; secondly, how new school buildings were built and thirdly, how a new form of teacher and a new teachers' education was enacted at different stages across the King's realm and countries, and with very different consequences.
\end{abstract}

Keywords $\bullet$ Mass schooling, school acts, school administration, teacher education, new school buildings

\section{Introduction}

In 1780, there were two schools in the parish of Magleby in the southern part of Sealand: one in Magleby and one in Stigsnæs. ${ }^{1}$ Combined, the schools had approximately 80 pupils in the 6-15 age-range. Around a quarter of the pupils attended school in Magleby, the rest in Stigsnæs. Søren Pind (1739-1811) was the headmaster at Stigsnæs School. He had no formal teacher training but this was not a requirement. Pind started each day of teaching with a morning hymn from the Lutheran psalmbook and a prayer with the assembled children, who were kneeling during the prayer. At the end of the prayer, he would read a passage from the Bible after which the children would each continue where they had left off in their school books. Not all of the 60 pupils attended every day. During the spring and autumn, in particular, there was much agricultural work to attend to and the children were required to help their farming families. Because of that, many older children rarely attended school, only returning to revise during the winter, before their confirmations. ${ }^{2}$

The article is based on Christian Larsen, Erik Nørr and Pernille Sonne, Da skolen tog form: 1780-1850 [When Schools Were Shaped: 1780-1850], volume 2 of Ning de Coninck-Smith and Charlotte Appel, eds., "Dansk skolehistorie - hverdag, vilkår og visioner gennem 500 år" [Schools in Denmark: A History of Everyday Life, Conditions, and Visions over 500 Years] (Aarhus: Aarhus Universitetsforlag, 2013). The project was funded by the Carlsberg Foundation. The author of this article would like to thank his co-authors for permission to use their part of the book for the article, and the peer reviewers for valuable comments on early versions of this article.

1 The following is based on Johs. C. Jessen, Vester og Øster Flakkebjerg Herreds Skolehistorie (Copenhagen: ASAs Forlag, 1938), 24-25, 166-70.

2 C. Larsen et al. (2013), 14.

Christian Larsen is a Senior Researcher at The National Archives, Denmark.

Email: cla@sa.dk

Nordic Journal of Educational History 2017. () Christian Larsen. This is an Open Access article distributed under the terms of the Creative Commons CC-BY4.0 License (http://creativecommons.org/licenses/by/4.0/). 
Returning to southern Sealand 70 years later, an observer of the scholastic conditions of 1780 would have observed great changes. Superficially, there were fine new school buildings. At Stigsnæs, a new school had been built in 1820 after the old building had burnt to the ground. From 1834 to 1871, the teacher at Stignæs was Niels Lerche (1797-1886), who was educated at the teacher training college in Jonstrup. At the school, approximately 80 children were now divided into two classes, the smaller children in the lower class and the older in the upper. The classes had alternating school attendance, as there was only one teacher. ${ }^{3}$

Many of the changes seen at the schools in the Magleby parish can also be observed in the other parts of the Danish realm. In several instances, it is possible to point to specific paragraphs in the Danish School Acts of 1814 as the cause of these similarities. The 1814 school legislation demonstrated a desire to make schools a part of state business for which the government took responsibility; it issued guidelines for nearly all the conditions in a school, from personnel and curricula to buildings and discipline.

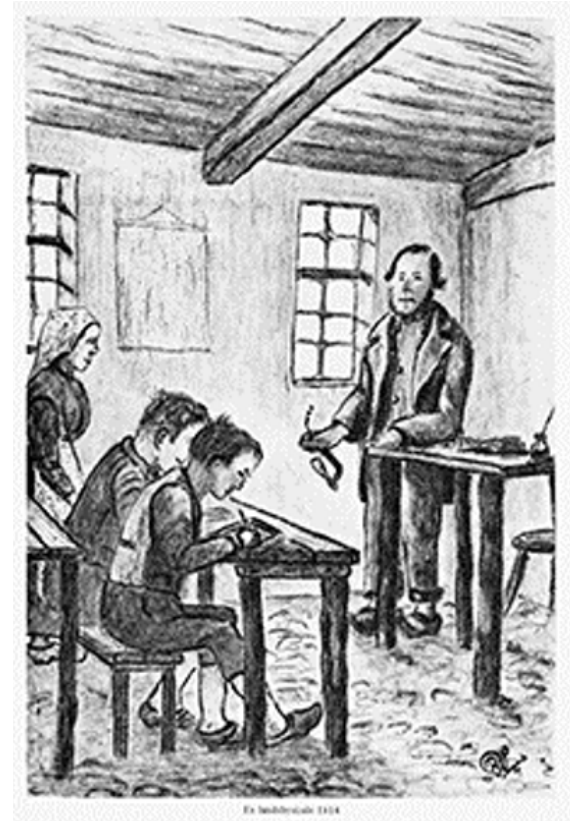

Figure 1. The drawing from 1957 is intended to give an impression of the conditions in a rural district school in the beginning of the nineteenth century.

Source: Ejnar Poulsen, Viborg Amts skole- og degnehistorie (Viborg: Ejnar Poulsen, 1957).

Both before and after 1814, however, there were considerable differences between schools attended by children of diverse backgrounds and from different areas. Throughout the period, a fundamental divide between children from the towns and children from the countryside existed. This was the reason that a series of parallel acts were passed, instead of a single school act. Differences included the number of school days and the choice of subjects. Additionally, children of differing social classes seldom attended the same school as the most privileged were educated separately. Gender was the other major separating factor. This was particularly prominent in families who educated their children beyond the elementary level. Boys typically

3 Jessen (1938), 26-27. 
attended school for more years than their sisters and were educated in a wider range of subjects at different locations and by different teachers. The future role for girls was marriage; therefore they did not need education beyond an elementary level.

There were also variations between the various realms of the Danish King. The school day was different in the German-speaking and commercially advanced towns of the Duchies of Schleswig and Holstein, as it was on the remote Faroe Islands in the North Atlantic or on the heaths of West Jutland with poor soils. The situation for a teacher at a private school, for the sons of wealthy families in Copenhagen, was quite different from one teaching peasant children on the island of Bornholm or teaching slave children in the Danish West Indies.

In this article, I will highlight and analyse the impact of the 1814 School Acts and thereby the emergence of mass schooling in Denmark in the nineteenth century. Both the general school reforms, as well as the specific implementations during the period 1780-1850, are analysed in order to explain how schools and schooling were shaped. ${ }^{4}$ To appreciate these changes and also the relevant contexts in the period 1780-1850, three aspects of the 1814 Acts affecting the daily life of schooling and the emergence of mass schooling are analysed: 1) how a local school administration was built, 2) how new school buildings were built, and 3) how a new form of teacher and a new teachers' education was established. The focus will be on the rural districts, where almost 80 per cent of the population lived.

Two analytical approaches will be used to show how different types of schools have existed and been shaped by people and their surroundings at different times. The diversity approach deals with the changing school landscapes and with all the different people involved in everyday school life. In this article, I highlight variations and exceptions in order to show how schooling was experienced and assessed in widely differing ways, depending on where and for whom schools were organised. The struggle approach is applied to show how the school was an arena of negotiations and conflicts, nationally and locally. This influenced on organising the local school administration, on the building of new schools, or how to be a good teacher. For example, building new schools was not only a question of economy; it also depended on local traditions, negotiations over the layout of the school building, and conflicts between the local officials and the taxpayers.

In older historical portrayals of the Danish school, the changes in the period from 1780 to 1850 have often been interpreted in the light of two closely related conditions: first, the impact of new educational trends and secondly, the 1814 school legislation.

To a great extent, the history of Danish schools has been seen as a history of progress. In ancient times, there were few schools and they were in a poor condition. However, the 1780s and 1790s brought new ideals and with them, reforms; this resulted in the School Act of 1814 and the creation of a unified, centrally organised Danish school system. In this context, the 1814 School Act, which among other things ruled that all children should have seven years of schooling, became a land-

4 The study is based on a large amount of printed and unprinted materials, see C. Larsen et al. (2013), 357-401, for a more detailed description. The unprinted material emanated, among others, from archives from the Danske Kancelli, school directors, school boards and schools, reverends, teacher training colleges, estates, police and reformatories. Among the printed material are contemporary literature and debates, memories and textbooks, as well as Danish and international literature. 
mark and the basis of "the Danish public school" (den danske folkeskole). This tale got its classic design in school headmaster Joakim Larsen's books on the history of the Danish public school. ${ }^{5}$ The $1784-1818$ volume is a broad presentation of Danish school history in this period, which, for Larsen, stood as the most central: A unified Danish school system was finally established, the school thereby becoming "the system of which it essentially retains the present days," and when the educational debates was of "enduring importance." ${ }^{6}$ Therefore, 1814 was the significant year, above all others, in the history of the Danish public school.

Many have since repeated this interpretation and 1814 has remained the central anniversary of the public school system. Therefore, in many books and articles, the history of Danish schools has been divided into "before" and "after" 1814 . The interest focused on school as an institution, with the Act as the phenomenon that created the framework of schooling. Regarding the local conditions for schooling, focus was primarily on when and to what extent local communities managed to implement the statutory provisions. It also meant that children's education organised in other ways - for example, home schooling or small informal private schools - was seen as "wrong," almost by definition.?

The history of Danish schools has largely been written as a national story of how 'the Danish people' received its schools. Moreover, many books and articles have emphasised conditions that were common within the Kingdom's borders and across social boundaries, whilst regional and social differences have been downplayed. Finally, older Danish school history has primarily been written 'from above', that is with a focus on those in power, their motives and deeds, with particular interest for individuals who made a difference. Teachers and children generally constituted those groups that were provided with school legislation and resources by the government and the civil service and parents were rarely mentioned at all.

Another form of school history focused on the development of educational ideas. For the period 1780-1850, researchers have particularly highlighted Jean Jacques Rousseau's book Emile as an important source of inspiration for other educational thinkers, including J.H. Basedow and J.H. Pestalozzi. These men further developed Rousseau's thoughts on a more child-friendly pedagogy and experimented with different kinds of schools. The new educational vision was seen as the driving force for those who reformed the Danish school system, including the brothers Ludvig and C.D.F. Reventlow, both noble landowners and central political figures. ${ }^{8}$

5 Joakim Larsen, Bidrag til den danske Folkeskoles Historie 1784-1818 (Copenhagen: V. Thaning \& Appel, 1893 - reprinted 1984).

6 J. Larsen 1893/1984, introduction, page 1 ("fordi Folkeskolen i dette Tidsrum modtog den ydre Ordning, som den i Hovedsagen har bevaret til vore Dage [...] en Drøftelse af pædagogiske Spørgsmaal, der rummer meget af blivende Betydning").

7 This applies, for example, to Den Reventlowske Skole i 150 Aar. Skoleliv ved Brahetrolleborg (Svendborg: Svendborg Amts historiske Samfund, 1933); Hans Kyrre, Vor Skole, dens Liv og Love (Copenhagen: Gjellerup, 1933); Aksel H. Nellemann, Den danske skoles historie (København: Gjellerup, 1966); Tage Kampmann et al., Et folk kom i skole 1814-1989 (Copenhagen: Institut for Dansk Skolehistorie, 1989), and Harry Haue et al., Skolen i Danmark fra 1500-tallet til i dag (Aarhus: Systime, 1986). These narratives can be found in general works on the history of Denmark, such as Olaf Olsen, ed., Gyldendal og Politikens Danmarkshistorie (Copenhagen: Gyldendal \& Politikens Forlag, 1986-1992, 2nd ed. 2002-5), volume 9 (Ole Feldbæk, "Den lange fred 1700-1800") and volume 10 (Claus Bjørn, "Fra reaktion til grundlov 1800-1850").

8 K. Grue-Sørensen, Opdragelsens historie, 1-2 (Copenhagen: Gyldendals pædagogiske bibliotek, 1956-59). 
To a great extent, the main interest in this field of research has revolved around the ideas and phenomena that pointed "forward," while teaching methods, which emerged but since disappeared, did not receive the same attention. A notable exception is the so-called Bell-Lancaster method, which was predominant from the 1820 s and the following two decades. However, it is characteristic that the method has often been seen as inappropriate and doomed to failure, perhaps because historians knew that the method was abandoned - and that it was contrary to their own pedagogical ideals. ${ }^{9}$

More recent research has increasingly linked school history along with social development, especially agricultural reforms and the emergence of a stronger state. Some researchers have focused on the state's role as educator of the children, seeing the school and school reforms as the state's instrument of ideological and social disciplining of the subjects. These researchers have wanted to make a stand with the older and more idealising representations of school as something unequivocally positive. ${ }^{10}$ Other researchers have shifted the focus away from the major ideologies and instead, studied the interaction between authorities and the local population in daily school life. ${ }^{11}$

In this article, I built on the present research but my approach differs in several respects from the traditional writing of school history in Denmark (seeing the schools from above) and is therefore largely based on new studies. Recent international research trends, in addition to the Danish research tradition, have had an impact through the use of, inter alia, micro-historical approaches to highlight the conditions of everyday life and diversity, seeing the schools from below. ${ }^{12}$ Micro-historical approaches enable us to see how the emergence of mass schooling in Denmark was not a linear process but consisted of a number of parallel processes, where economical, political, and local conditions played a major role in the process of enacting new school Acts and the emergence of mass schooling.

Schooling in 1850 was in many ways similar to the situation in 1780 , as Denmark continued to be a patriarchal society with a large contrast between rich and poor,

9 See, for example, J. Larsen (1898/1984), 14-44.

10 Ingrid Markussen, Visdommens loenke: Studier i enevoldens skolereformer fra Reventlow til skolelov (Odense: Landbohistorisk Selskab, 1988), and Til skaberens cere, statens tjeneste og vor egen nytte: Pietistiske og kameralistiske idéer bag fremvoksten af en offentlig skole i landdistrikterne i 1700-tallet (Odense: Odense Universitetsforlag, 1995). Niels Reeh, Religion and the state of Denmark - state religious politics in the elementary school system from 1721 to 1975 (Ph.D. diss., Copenhagen University, 2006), and Secularization Revisited: Teaching Religion and the State of Denmark 1721 to 2006 (New York: Springer, 2016).

11 Erik Nørr, Prost og administrator: Sogneprcestens funktioner i lokalforvaltningen på landet fra 1800 til 1841 (Copenhagen: Rigsarkivet, 1981); cf. Erik Nørr, Pfarrer und Administrator: Die Funktionen des Gemeindepfarrers in der ländlichen Lokalverwaltung 1800-1841 (Copenhagen: Rigsarkivet, 1984); Erik Nørr, Skolen, prosten og kommunen: Kampen om skolen på landet 1842-1899 (Copenhagen: Jurist- og Økonomforbundet, 1994).

12 See Steve Mintz, Huck's Raft: A History of American Childhood (Cambridge Mass.: Harvard University Press, 2004); Nicholas Stargardt, Witnesses of War: Children's Lives under the Nazis (London: Jonathan Cape, 2005) as examples of diversity in writing history with regards to schools, as well as children's lives. The present article's emphasis on everyday school life is a continuation of the discussion in Paedagogica Historica on the history of the school's everyday life and its source material. See Marc Depaepe and Frank Simon, "Is there any Place for 'Education' in the 'History of Education'? A Plea for the History of Everyday Educational Reality in- and outside Schools," Paedagogica Historica 31, no. 1 (1995), 9-16, and Marc Depaepe, "The Ten Commandments of Good Practices in History of Education Research," in Marc Depaepe, Between Educationalization and Appropriation (Leuven: Leuven University Press, 2012), 463-70. 
men and women. ${ }^{13}$ There were, however, major shifts in the social structures, which influenced the development of Danish schools. Some of the most significant changes were related to the agrarian reforms (landbrugsreformerne), which introduced new crops, cultivation methods and farmers' responsibility for their own plots. ${ }^{14}$ This meant the emergence of a stronger and more independent farmer class, with new needs and expectations of schooling for their children. Agricultural reforms also led to significant productivity gains and thus, better nutritional status and further population growth.

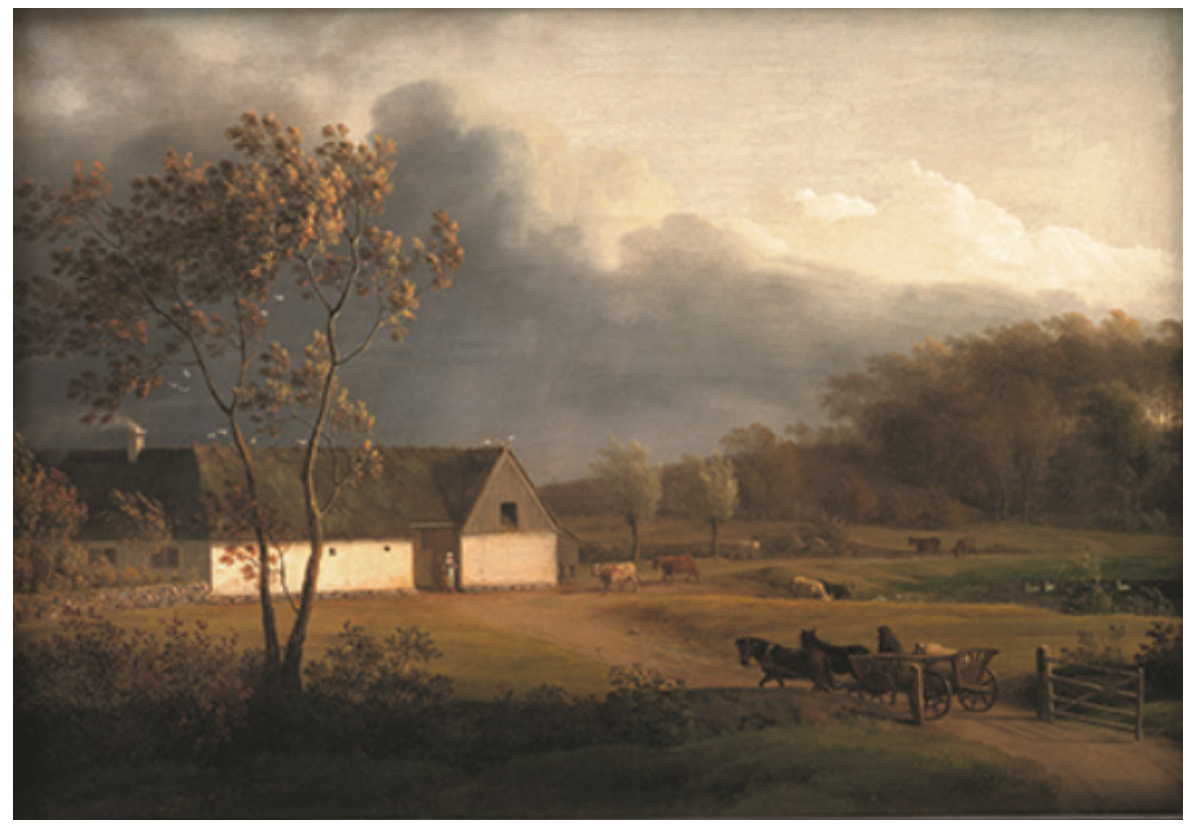

Figure 2. One of the most significant changes related to the agrarian reforms was the dissolution of the old village community and the relocation of the farms into the fields. It also meant longer school journeys for the children. Source: Statens Museum for Kunst, Jens Juel, "En sjællandsk bondegård under et optrækkende uvejr. Eigaard ved Ordrup” (ca. 1793), Copenhagen.

The economy was not characterised by sheer growth. The state went bankrupt in 1813, reflecting the large war expenses from the Napoleonic wars, in particular. Shortly after, an agricultural crisis began, with low prices on the farmers' crops. It produced great challenges for the implementation of the newly adopted School Acts of 1814 as the farmers could not pay schools taxes. The economic cycle turned in the 1830s. ${ }^{15}$

From 1780 to 1850 , there were major political, religious and cultural changes. The Enlightenment's optimistic belief in human potential and the desire for secure, better education for the population, especially through schools, was challenged by more

13 C. Larsen et al. (2013), 24-26.

14 There is an extensive literature on the Danish agrarian reforms (Landboreformerne). The latest study is Birgit Løgstrup, Bondens frigørelse: De danske landboreformer 1750-1810 (Copenhagen: Gad, 2015).

15 Ole Feldbæk, Danmarks økonomiske historie 1500-1840 (Herning: Systime, 1989). 
conservative forces. The period also includes shifts from a cult of patriotic virtues and fidelity towards the King within the framework of a composite Oldenburg monarchy to an increasing focus on the love of the mother tongue and the motherland, in a more narrow national sense. ${ }^{16}$

These trends were closely linked to the political changes of this period. From 1660 to 1848 , the Danish kings were autocratic rulers and this created considerable continuity. However, there were many changes in the autocratic state apparatus, including major changes to the administrative structures, which were gradually necessitated by agricultural reforms. Schooling was one of several areas - beside relief for the poor - where the state increasingly took on overall responsibility, while local administration expanded. Furthermore, groups of citizens and more prosperous peasants took part in the administration of and debate on schools and community during the 1830 s and especially the 1840s, in the printed public debate, the advisory assemblies (rådgivende stoenderforsamlinger) and not least, in local administration. ${ }^{17}$

\section{The School Acts of 1814}

In Denmark, it is common to talk of the School Act of 1814; in reality, there were five Acts. Three of these were launched on July 29, 1814. They set the standards for schools in different parts of the country. ${ }^{18}$ One concerned the rural districts, another market towns and the third the capital - Copenhagen - in the Kingdom of Denmark. Two other Acts concerned the Jews within the Danish Kingdom ${ }^{19}$ and the Danish king's Duchies of Schleswig and Holstein. ${ }^{20}$

Several key elements of the 1814 laws had their roots in the reform period of the 1780 s and 1790s with its debates, the 1789 Great School Commission and the 1806 Provisional School Act for the islands of Zealand, Lolland-Falster and Funen. ${ }^{21}$ The idea was that the public school system should extend knowledge beyond the Christian scriptures, that school should play a more important role in the lives of all children and that the state should take responsibility for the country's public school system. Experiences gained in earlier reforms of private and the gentry's schools became central to the new thoughts concerning schools.

However, the laws of 1814 cannot simply be understood as late or delayed results of the foresaid reform period. Other agendas had emerged over the years. These con-

16 See Tine Damsholt, Foedrelandskerlighed og borgerdyd: Patriotisk diskurs og militoere reformer i Danmark i det sene 1700-tal (Copenhagen: Museum Tusculanum, 2000); Juliane Engelhardt, Borgerskab og foellesskab: De patriotiske selskaber i den danske helstat 1769-1814 (Copenhagen: Museum Tusculanum, 2010); Rasmus Glenthøj, Foelles kultur - forskellige nationaliteter: De borgerlige eliters skabelse af en national identitet i Danmark og Norge 1807-30 (PhD diss., University of Southern Denmark, 2010).

17 Tim Knudsen, Fra eneveelde til folkestyre: Dansk demokratihistorie indtil 1973, 2nd edition (Copenhagen: Akademisk, 2007), 51-116.

18 C. Larsen et al. (2013), 127-47. The drafts and the final Acts are printed in Joakim Larsen, ed., Skolelovene af 1814 og deres Tilblivelse, aktmossigt fremstillet, udgivet $i$ Hundredaaret for Anordningernes Udstedelse (Copenhagen: J.H. Schultz, 1914).

19 Det Jødiske Frihedsbrev, $\$ \$ 14-20$, http://danmarkshistorien.dk/leksikon-og-kilder/vis/materiale/ det-joediske-frihedsbrev-af-29-marts-1814, January 23, 2017.

20 The School Act for the Duchies of Schleswig and Holsten is printed in Ernst Erichsen and Hermann Sellschopp, ed., Die allgemeine Schulordnung für die Herzogtümer Schleswig und Holstein vom 24. August 1814 (Kiel: Ferdinand Hirt, 1964), 61-91.

21 C. Larsen et al. (2013), 82-89. 
cerned the desire for tackling the poor and uneducated children in urban areas and to control the unchecked school reforms, particularly in the capital. The poor laws of 1799 and 1803 had made schooling compulsory for children in the care of the poorlaw authorities. A third important factor was the interest of the state in bringing up loyal subjects, willing and able to defend King and Country. In addition to this, a new understanding of citizenship (borgerdyd) and nationhood (foedrelandskoerlighed) resulted in a greater focus on the need to raise children towards patriotism and loyalty to the absolute monarch. Study trips to model schools abroad, during the preceding decades, the dissemination of foreign pedagogic writings and a widespread production of pedagogic literature must also be seen as important parts of the background to the new legislation. ${ }^{22}$

In several respects, the 1814 agenda differed from the optimistic formulae of the 1780 s and 1790s. The cultural and high political tendencies in Europe had contributed to these developments. The optimism of the enlightenment had given way to a more conservative current, influenced, amongst other factors, by the developments in France where the revolutionary Republic had been eclipsed by Napoleon's Empire. In 1805, the Danish Ministry of Justice, Church and Education, Danske Kancelli, had rejected the introduction of teaching history, geography, natural science, natural history and mechanics as separate subjects with the reasoning that: "it is to be feared that by going too far in these matters one might remove the peasant from his real occupation." ${ }^{23}$

The final Act, concerning rural districts, only referred to farmers (almuen or bønder), that is not children from other social classes, such as the children of clergymen or landowners. The sons and daughters of the clergy, civil servants, wealthy landowners or manufacturers, could not be satisfied with the common standard of education; they were expected to attain a higher level of education. It would also be unthinkable that the two groups of children should share the same school and daily life. There were differences between people and the general opinion was that this should continue. Finally, it was considered perfectly natural that the wealthy should pay for their own children's education and not avail themselves of the free option. ${ }^{24}$

Similar principles governed the school systems in the market towns. The market town Act was prepared in parallel with the rural districts Act and they have similarities. There were, however, some differences. In the largest cities, there should be two kinds of schools: a common school (borger-eller almueskole), and a realskole. The common schools were meant for the city commoners (byalmuen) and corresponded to the rural commoners' schools. The realskole had a far more advanced education than the common school and was intended for sons of wealthy city inhabitants. Another important difference was that peasant children had to go to school every other day whilst labour schools were to be organised in the market towns so children without paid work could be kept employed outside school hours.

22 C. Larsen et al. (2013), 128.

23 "da det er at befrygte, at man ved at gaae for vidt i denne Henseende kunde drage Bonden fra sin egentlige Bestemmelse," J. Larsen (1914), 340.

24 C. Larsen et al. (2013), 132-33. 


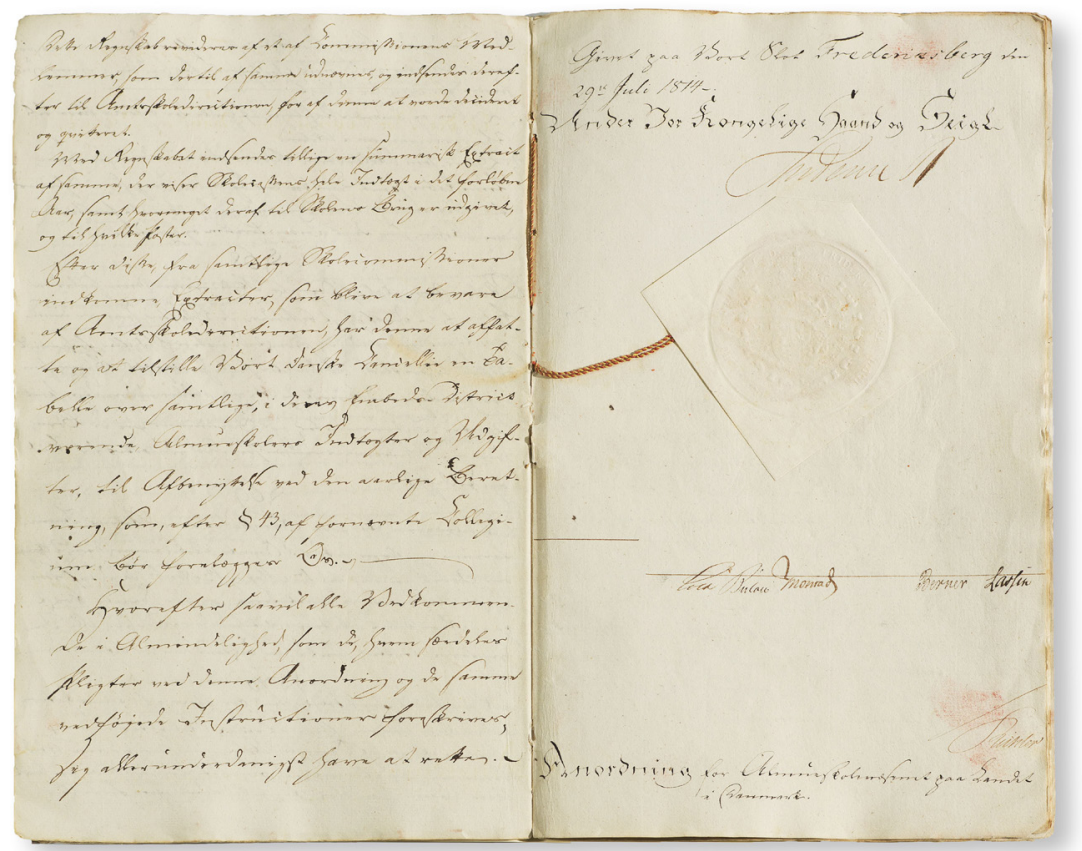

Figure 3.25 years after the establishment of the Great School Commission, King Frederik could sign the School Acts. Source: Rigsarkivet København, Danske Kancelli, Fællesafdelingen for samtlige departementer, Originale forordninger og plakater etc. 1800-1848, pakke 1814-1821.

The twin goals of education in the rural districts and in the market towns were to be "the dissemination of true religiosity and the promotion of good citizenship" 25 and were reflected in the curriculum: Christianity, reading, writing and arithmetic. History, geography and other useful skills were still to be integrated with instruction in reading and writing. ${ }^{26}$ As an innovation, boys were to learn gymnastics if the teacher was able to instruct them in the subject. ${ }^{27}$ Gymnastics was intended to prepare the peasant boys for their time as conscripts, partly through physical training and partly to train them to obey commands and to march.

In Copenhagen, the capital of the realm, conditions were different to the market towns. Therefore, a board of directors was given the overall responsibility for all city schools. ${ }^{28}$ The public schools were to have three classes in contrast to rural and market town schools with two classes, but the third class was not mandatory and school fees were charged. ${ }^{29}$ In the public schools, children were moulded into good, educated and hard-working human beings and citizens. ${ }^{30}$ However, education should be segregated and with a different curriculum for boys and girls.

The law of March 29, 1814, concerning Jews, differed in several respects to the other laws. This Act was more a general definition of the Jewish community's rights

25 "udbrede sand Religiøsitet og fremkalde borgerlige Dyder,"1814 School Act concerning rural districts, preambel, J. Larsen (1914), 414.

26 J. Larsen (1914), 511-12.

27 J. Larsen (1914), 512.

28 J. Larsen (1914), 551.

29 J. Larsen (1914), 552-557.

30 J. Larsen (1914), 552. 
and duties and it did not directly refer to education or schooling. It did, however, contain elements that made an oath of loyalty and religious examination a duty for all Jewish youths. The religious examination was in many ways similar to the ritual of confirmation in the state church and required, in the same way, a preparatory education. Seen in this perspective, the Act regarding Jews is just as much a school Act as the previously mentioned school Acts but it made no demands as to how this education should be organised. ${ }^{31}$

Schleswig and Holstein were duchies of the Danish King but were subject to a different constitution, demography, economy and educational traditions than the Kingdom. Therefore, the same law could not be applied here. The new Act, promulgated in Danish and German, applied to burgher schools in the small towns and market towns (or "hamlets" as they were called) and countryside schools. The school Act asserted that the goal of education in rural districts was not merely the teaching of reading, writing and religion, but was also to include necessary and useful skills, especially those appropriate to the children's future as farmers. ${ }^{32}$

Not all parts of the Danish King's realm received new legislation. With the 1813 Treaty of Kiel, Frederick VI ceded the Kingdom of Norway to the King of Sweden. The new Act therefore had no effect in Norway. The original plan was that the legislation should apply to market towns in both countries. On the other hand, it had never been the plan that the act concerning rural schools should also cover the rural districts where daily life was far removed from that in the Danish countryside. ${ }^{33}$

Reform of public schooling in the farthest reaches of the Danish king's territories was also not broached. Schools in the northern territories (Iceland, the Faroes and Greenland) and those in the tropical colonies (in the West Indies, India and Africa) were a widely different phenomenon to those in the heartlands. ${ }^{34}$ Therefore, in the lands beyond Copenhagen, 1814 marked no historic change in scholastic conditions.

\section{A new local school administration}

The emergence of mass schooling in Denmark depended on many things. However, the institutionalisation of the school, that is creating an organisation to carry out the King's commands, played a central role in this process as it supported the implementation of the Acts.

One of the essential innovations of the 1814 legislation was that the whole organisation of schooling and schools changed and that the responsibility for this passed partially into new hands. ${ }^{35} \mathrm{~A}$ new administrative structure was introduced with local school boards (skolekommissioner) consisting of representatives of (the social superior part of) the rural population in the school district (skoledistrikt). The skoledistrikt was similar to the Swedish skoldistrikt, the German Schulsozietäten and the American school districts. ${ }^{36}$

31 Det Jødiske Frihedsbrev, $\$ \$ 14-20$, http://danmarkshistorien.dk/leksikon-og-kilder/vis/materiale/ det-joediske-frihedsbrev-af-29-marts-1814.

32 Erichsen and Sellschopp (1964), 73-76.

33 C. Larsen et al. (2013), 145-47.

34 C. Larsen et al. (2013), 275-89.

35 Nørr (1981), 36-67; Larsen et al. (2013), 291-303.

36 Johannes Westberg, Att bygga ett skolväsende: Folkskolans förutsättningar och framväxt 1840-1900 (Lund: Nordic Academic Press, 2014), 21. 
In all school boards there were to be two "school principals" (skoleforstandere) appointed from the parishioners by the county school directors. In the 1780 s, some of the most active landowners had tried to involve leading parishioners to make them take responsibility for the local school. This was inspired by the system already in place in Norway from 1741. Here "four of the most knowledgeable and best men" 37 in each parish, as well as the sheriff and parish pastor, were responsible for the parish schools. The involvement of the local population seems to have made a difference for both the development of the local school and its legitimacy and connection to the community. At the same time, membership of the commissions conferred experience in school and local politics to new generations. They were granted limited influence, though this did increase after the introduction of local self-government in 1837 and $1841 . .^{38}$

A plan for each parish's public schools (skoleplan) was to be established by the parish's school board and approved by the Danske Kancelli. The plans were to include information on the school districts' size and the number of schools, the teachers who were to conduct the teaching, their salaries, as well as how the expenses of the schools had to be paid. Planning was compulsory but its form varied. ${ }^{39}$

Therefore, each parish gained its own school plan that contributed to the large regional and local variances. The economic downturn from 1813 meant that approval of school plans fell and it was from around 1830 that the first preparation of plans was revived as the economic trends improved for the country's main business, agriculture. ${ }^{40}$ In the mid-1830s, 263 parishes or 16 per cent of all Danish parishes did not have a school plan; that is a school plan not yet in force or no plan at all. This applied particularly to the island of Funen and the western part of Jutland. ${ }^{41}$

One of the key tasks for the newly established school boards was to make sure that the children went to school on a regular basis. The school Acts of 1814 reinforced compulsory education (undervisningspligt; i.e. a duty to receive education), introduced in 1739. The developments over the following decades show that these laws were perceived and enacted as compulsory school attendance (skolepligt, i.e. a duty to go to a school) for the majority; that is children of peasants and labourers. ${ }^{42}$

Schooling was regularly met with opposition from parents and masters who prioritised children's and domestics' work over frequent schooling. They had to get used to the fact that their children's and domestics' schooling was now governed by the Acts, in principle, and that others - teachers, pastors and school boards - had the right and duty to intervene. ${ }^{43}$ School absences were a nationwide problem through-

37 "4re af de kyndigste og beste Mænd," 1741 Norwegian school Act, $\$ 2$. See Charlotte Appel and Morten Fink-Jensen, Da loereren holdt skole: Tiden før 1780 (Aarhus: Aarhus Universitetsforlag, 2013), 214.

38 Nørr (1994); Niels Clemmensen, Konflikt og konsensus: Det landkommunale selvstyre i Danmark $i$ det 19. århundrede (Copenhagen: Museum Tusculanums Forlag, 2011).

39 Larsen et al. (2013), 149-53.

40 Larsen (1898), 45-46.

41 "Most humble report on the state of the schools in Denmark, except Copenhagen," October 20, 1837, The Danish Chancellery, 1 Department. H54-2, Various school reports. Various reports concerning public schools, 1805-37. The Danish National Archives, Copenhagen. C. Larsen et al. (2013), 155-56.

42 C. Larsen et al. (2013), 132-35.

43 C. Larsen et al. (2013), 294-98; Pernille Sonne, "Kampen om børnenes tid : hensynet til arbejdslivet i Almueskoleloven af 1814," Kirkehistoriske Samlinger (2015). 
out the nineteenth century. If children missed school without a legitimate reason, the school board had to impose a fine (mulkt) on the parents or masters. However, within the boards, where parents and employers were represented, there was no clear support to enforce the school Acts' requirement of regular schooling. Several boards did not impose fines or adhered to the lowest fine tariffs, or they ignored children not going regularly to school. As Denmark was struck by an agricultural crisis, the number of fines increased considerably, as the parents needed the children's labour. When the crisis slowly ebbed and there was more wealth, the picture scarcely changed and there were very few fines imposed, compared to the extent of missed school days. ${ }^{44}$

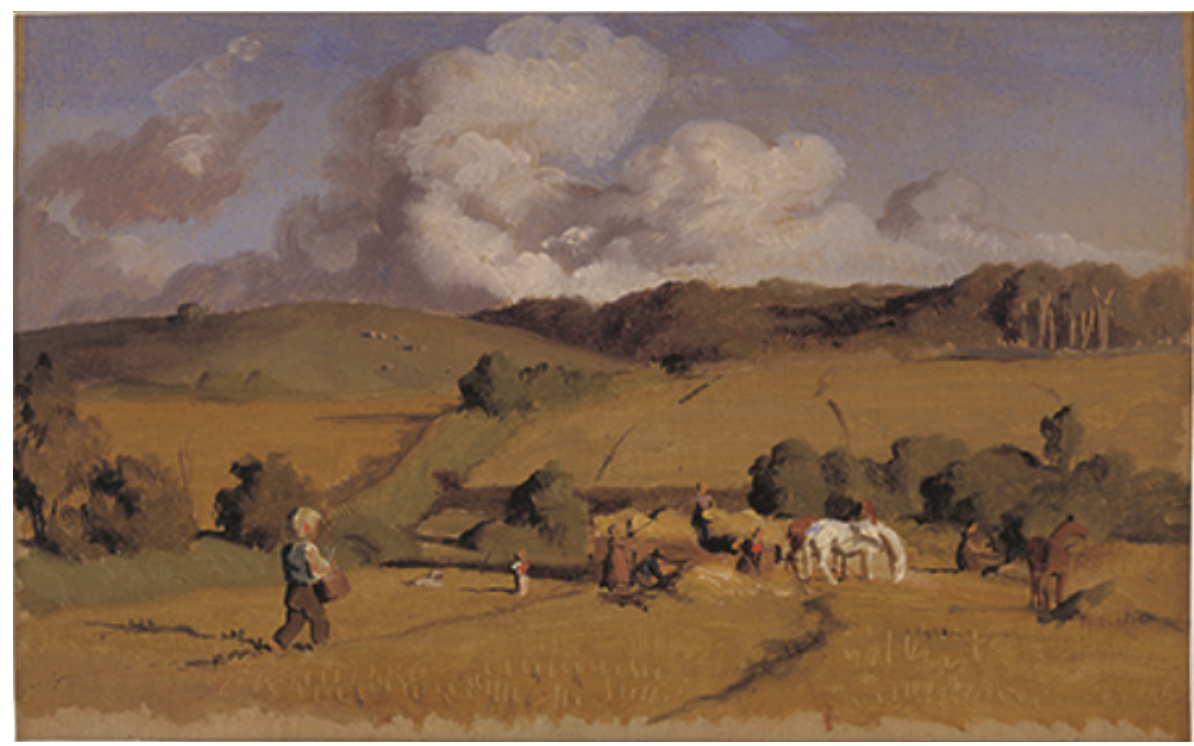

Figure 4. School absences were a nationwide problem in the nineteenth century as work played a major role for most children. In the picture, a boy is on his way across the field with a basket, presumably filled with food to the harvest workers. Source: Statens Museum for Kunst, Lorenz Frølich, "Landskab fra Holmstrup" (1845), Copenhagen.

The institutionalisation laid a good foundation for the local implementation of the school acts in a period where the state only could play a minor role. Placed in Copenhagen - far from the everyday life in the small towns and villages - the state needed the help and support of the local communities. However, local conditions and opposition meant that implementation varied from district to district.

\section{New schools rise over the country - building schoolhouses}

Another key element in the emergence of mass schooling - and a major change in everyday school life - was the construction of permanent schoolhouses. Schoolhouses were seen as a precondition for the implementation of the school acts and for securing better conditions for the education of children.

One of the main tasks for the newly established school boards was providing the

44 Det Statistiske Bureau, Om Almueskolevoesenet paa Landet i Danmark i 1857, Statistiske Meddelelser 1, række, 5. bind, 3. hæfte (Copenhagen: Det Statistiske Bureau, 1859), 101-2. 
parish with one or more schoolhouses. According to the rural district school Act, the classroom should be roomy and there should be at least 2.5 meters from the floor to the beams. Roof, doors and windows should be tight and the windows should be able to be opened. The floor should consist of boards or bricks. The school building should provide the teacher with a "decent room for themselves and family as well as sufficient space for two cows and six sheep, to retain his feed and wood and the procreation from the school's soils." ${ }^{35}$ If circumstances permitted it, there should be a small garden for the school teacher, where he could grow vegetables and fruits. The cost of school buildings was to be paid by the parishioners.

In many places in the countryside, there had been adequate school buildings for several generations. These were especially common where the local landowner, or his representative, had seen it as their duty to secure a roof over the heads of teachers and pupils. During the 1720 s and particularly in the east of Denmark, a considerable number of schools were constructed; amongst others, King Frederick IV's schools on crown estate (rytterskoler). Schools were also constructed in the wake of the school law of $1739 .{ }^{46}$ In the 1780 s and 1790s, there was another wave of school construction, often in conjunction with school reform on private estates. Other areas had proceeded differently. Here, for example, schools were constructed as an extension of the parish dean's manse, in an old barn or in a vacant building of variable quality. In market towns and in Copenhagen, the buildings occupied by schools also differed widely. ${ }^{47}$

Permanent schoolhouses were prioritised, even in the difficult economic times following state bankruptcy in 1813, and during the 70 years from 1780 to 1850 the vast majority of schools were established in their own buildings. It was a growing expectation that a school was a solid physical place. A survey made by the Danske Kancelli in 1836 showed that 605 new rural schools had been built since 1814, along with 305 new classrooms and 857 expansions to existing schools (Table 1). As a result, a quarter of schools were newly-built but the vast majority still stemmed from the 1700s. The construction costs amounted to a total cost of 859,000 Rigsbankdaler (rbd) or what corresponded to nearly two years of elementary school expenses. On average, $375 \mathrm{rbd}$ had been used per school; however, this ranged from $657 \mathrm{rbd}$ on the island of Funen with good and rich soils to $199 \mathrm{rbd}$ in the meagre heathlands of West Jutland..$^{48}$

45 "[...] anstændigt Huusrum for sig og Familie samt den fornødne Leilighed til 2 Køer og 6 Faar, saa og til at bevare sit Foder og Brændsel samt den ham tillagte Jords Avling," 1814 school Act concerning rural districts, $\$ 52$, J. Larsen (1914), 428.

46 Appel and Fink-Jensen (2013), 177-78, 196-97.

47 C. Larsen et al. (2013), 165-75.

48 "Most humble report on the state of the schools in Denmark, except Copenhagen," October 20, 1837. The Danish Chancellery, 1 Department. H54-2, Various school reports, Various reports concerning public schools, 1805-37, The Danish National Archives, Copenhagen. 
Table 1. Rural school buildings, 1836

\begin{tabular}{|c|c|c|c|c|c|c|}
\hline Diocese of & $\begin{array}{l}\text { Number of } \\
\text { schools }\end{array}$ & $\begin{array}{l}\text { Newly-built } \\
\text { schoolhou- } \\
\text { ses }\end{array}$ & $\begin{array}{l}\text { Newly-built } \\
\text { school } \\
\text { rooms }\end{array}$ & $\begin{array}{l}\text { Extension } \\
\text { to or repair } \\
\text { of existing } \\
\text { schools }\end{array}$ & $\begin{array}{l}\text { Total } \\
\text { construc- } \\
\text { tion costs } \\
\text { in Rigs- } \\
\text { bankdaler }\end{array}$ & $\begin{array}{l}\text { Construc- } \\
\text { tion cost in } \\
\text { Rigsbank- } \\
\text { daler per } \\
\text { school }\end{array}$ \\
\hline Zealand & c. 590 & $179(30 \%)$ & 35 & 235 & 228,047 & 386 \\
\hline $\begin{array}{l}\text { Lolland and } \\
\text { Falster }\end{array}$ & 132 & $38(28 \%)$ & 10 & 58 & 57 & 431 \\
\hline Funen & 228 & $90(39 \%)$ & 52 & 83 & 149,993 & 657 \\
\hline $\begin{array}{l}\text { Aalborg } \\
\text { (northern } \\
\text { part of } \\
\text { Jutland) }\end{array}$ & 279 & $83(29 \%)$ & 48 & 83 & 107,173 & 384 \\
\hline $\begin{array}{l}\text { Viborg } \\
\text { (central } \\
\text { part of } \\
\text { Jutland }\end{array}$ & c. 250 & $60(24 \%)$ & 29 & 89 & 51,255 & 205 \\
\hline $\begin{array}{l}\text { Aarhus } \\
\text { (eastern } \\
\text { part of } \\
\text { Jutland) }\end{array}$ & c. 430 & $109(25 \%)$ & 54 & 189 & 169,094 & 393 \\
\hline $\begin{array}{l}\text { Ribe (wes- } \\
\text { tern part of } \\
\text { Jutland) }\end{array}$ & 481 & $50(10 \%)$ & 77 & 120 & 96,449 & 199 \\
\hline & 2,290 & 609 & 305 & 857 & 859,011 & 375 \\
\hline
\end{tabular}

Source: "Most humble report on the state of the schools in Denmark, except Copenhagen," October 20, 1837, The Danish Chancellery, 1 Department. H54-2, Various school reports, Various reports concerning public schools, 1805-1837. The Danish National Archives, Copenhagen. The number of rural schools in dioceses of Zealand, Viborg and Aarhus is an estimated number.

The Danske Kancelli issued guidelines concerning how to construct a good school building and school boards were responsible for implementing the guidelines. However, the demands met resistance in many places and school boards succeeded in delaying building projects for several years. The Acts of 1814 were instrumental in the emerging uniformity of schoolhouses, followed by architects' sketches of so-called model schools (modeltegning for mønsterskole) that were sent out all over the country by the government during the 1820 s. The government's so-called model school for the Kingdom was an extension of the school reform in the County of Sorø, in the early 1800s. This was, in turn, based on school reforms on the Crown estates in North Zealand in the 1780s and 1790s, which was an extension of the school reforms of the 1720s. Tradition played a prominent role in the design of the new schools. ${ }^{49}$

49 Architects' sketches of a model school, July 1829, The Danish Chancellery, 1 Department. Case no 1829/1864, The Danish National Archives Copenhagen. C. Larsen et al. (2013), 169-70. 


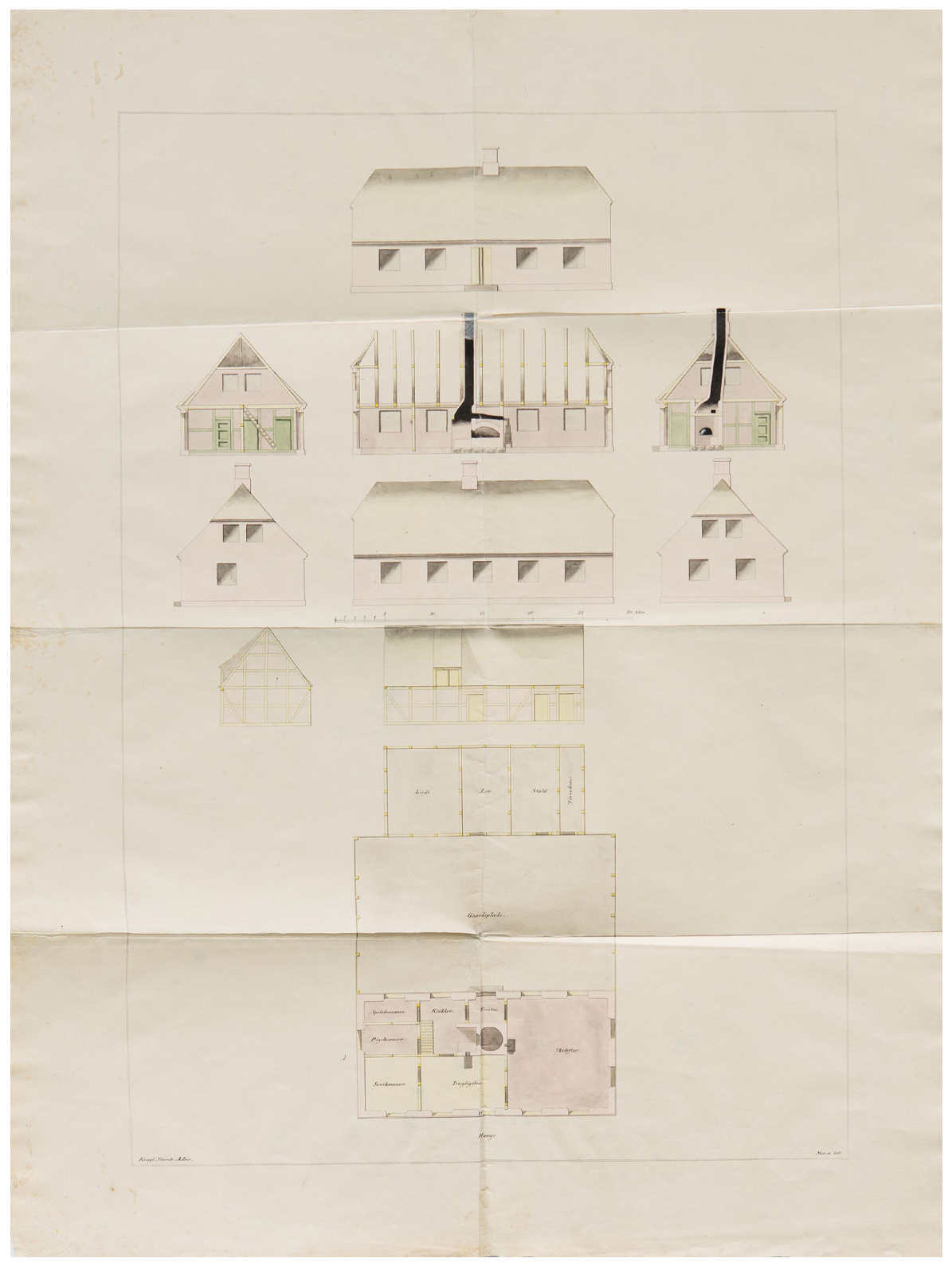

Figure 5. Architects' sketches of so-called model schools were sent out by the government in 1829 in order to secure uniformity of schoolhouses and to minimize building costs. Source: Rigsarkivet København, Danske Kancelli, 1. Departement, Brevsag 1829/1864.

Schoolhouses all over the country began to resemble each other but still with local variations. There were, for example, brick built rytterskoler with roof tiles from the 1720 s and the new spatial schools from the 1790 s on reformers' estates. There were also the older school buildings with a small extension, or newly-constructed schools with clay walls and thatched roofs which looked like the other village smallholdings. 
In market towns, the magistrate had to provide school facilities to the town's many children, which was a challenge in the economically hard times after 1813. In some towns, two schools were placed in the same building, or an older, abandoned school building was used again. In other places, the city magistrate had to rent rooms in private buildings. In the western part of Zealand, the school in Slagelse for children of more prosperous parents (borgerskole or betalingsskole) had its own spacious building whilst the school for the lower classes (friskole) was located in rented rooms. In Holbæk, the school occupied a part of a former monastery and in Kalundborg, the school had bought a house of its own.

School buildings were not only a question of economy, but also dependent on the number of pupils and the local building traditions. Disagreement about the scope and method of construction was also common. Was it, for example, really necessary to build a new-fangled gymnastic facility? Negotiations over the layout of a school building, both exterior and interior, is central to the understanding of how schools were understood by the main players, both centrally and in the local communities and also if one wishes to examine tensions between innovation and tradition.

In the middle of the 1850s, there were 2520 rural schools in Denmark. Schools on the islands of Zealand, Lolland-Falster and Funen with a higher degree of population density had (naturally) more pupils than schools in Jutland where the villages and farms could be far apart. On average, there were 80 children per school on the islands but only 53 children per school in Jutland. Also school buildings were larger on the islands in order to accommodate more children. The 1856 School Amendment Act provided 90 cubic feet of air per child. On the islands, 7 per cent of the schools had less than 50 cubic feet compared to 13 per cent of all schools in Jutland..$^{50}$

The construction of permanent schoolhouses was a key element in implementing the King's commands as they gave room for the children's education as well as the teacher's private apartment. At the same time, the structure of a school's permanent physical form had a great effect on its pupils even though there were variations in this form. For nearly all children, school attendance became more regular and lasted for a longer period of their childhood than had been the norm for previous generations. When one spoke of "going to school" in 1850, one referred to attendance at a particular building recognised as such by the whole local community.

\section{Educating new teachers}

Finally and not least, the implementation of the school acts depended on well-trained and skilled persons who were able to teach by the ideals set out by the acts. For the supporters of school reforms during the entire period, the education of primary level teachers was paramount if schools were to change and the School Acts were to be implemented throughout all parts of Denmark.

Previously, there had been no specialised education for teachers, even though there had been informal training undertaken by an enthusiastic dean or pastor. According to the school Act of 1739, priests were obliged to not merely supervise the local teachers' teaching but also to instruct the teachers how to teach. Teachers were from widely varying backgrounds. Some were no more than boys who had just left school after confirmation; some were old ladies who oversaw the education of the smaller children. Some were theologians, including many deans who filled the role

50 Det Statistiske Bureau (1859), 86-89. 
of teachers in their parishes. Others were clerks, artisans or even former soldiers. In some places, the teacher's pay was so poor that it was difficult to attract and retain good teachers, whilst in other areas the economic conditions were much better. ${ }^{51}$

When the clergy or gentry expressed a wish to reform the school system, focus lay on the teacher from the very beginning, precisely because the majority of schools were dependent on one single teacher and his teaching. The teacher was the school. To secure better teachers was therefore seen as the key to changing children's education. The establishment of a formal teacher training from the 1780 s onwards changed the role of teachers. In the German-speaking parts of Europe, in the early 1700s, state and church had created a new type of specialised teacher training: teacher training colleges or seminaries (loererseminarier). The idea came to Holstein, a duchy in the Danish realms, and the notion of a special education was formulated in legislation from 1747 . The plans were long in preparation, but in 1781, the vice chancellor of the University of Kiel in Holstein, J. A. Cramer, could open a state seminary, inspired by the school thoughts of German philanthropist, F. E. von Rochow. ${ }^{52}$ In Copenhagen, Blaagaard State College opened in $1791 .^{53}$ The Danish State had thus been given a new type of institution.

In the beginning of the 1800s, two types of colleges had arisen in the Danish realms: the kiel-blaagaardske state seminaries and the rectory seminaries (proestegardsseminarier). The colleges in Kiel, on Blaagaard and on Brahetrolleborg in Funen, offered a little longer and somewhat more theoretical training, influenced by Philanthropism and Rationalism. The eight rectory seminaries were set up by enterprising priests in the years $1802-16$ and located in the countryside, as there could be quite a distance from the rural villages to a state college. The teachers' training at the rectory colleges was generally shorter and cheaper and took place under close supervision from the priest but there were great similarities, too. In both kinds of seminaries, the teachers were inspired by the new educational trends and focused on giving the future teachers knowledge and specific teaching methods enabling them to teach in Christianity and the basic skills, as well as new and useful skills. ${ }^{54}$

In 1816 , a commission was set up consisting of the three oldest principals. There was a great difference in the statutes of the teacher training colleges as they had been formulated for over two decades. The government therefore wanted common rules for the colleges, resulting in the 1818 teacher training college statute (seminariereglementet). The colleges should train a religious, modest, practical and thrifty teacher. The future teacher should become accustomed to simplicity in everyday life, so his lifestyle suits the conditions of a teacher in a rural school amongst (other) peasants. The three-year general education should make the teacher able to teach, of course,

51 C. Larsen et al. (2013), 91-93.

52 Karl Knoop, Zur Geschichte der Lehrerbildung in Schleswig-Holstein: 200 Jahre Lehrerbildung vom Seminar bis zur Pädagogischen Hochschule, 1781-1981 (Husum: Husum Druck- und Verlagsgesellschaft, 1984); Franklin Kopitzsch, "Anfänge der Lehrerausbildung im Zeitalter der Aufklärung in Schleswig-Holstein, Hamburg und Lübeck," IZEBF: Information zur Erziehungs- und Bildungshistorischen Forschung (1983), 43-64.

53 J. Boisen Schmidt, Til duelige skoleholderes dannelse: Jonstrup Statsseminarium 1790-1990 (Lyngby: Jonstrups Venner, 1992); Ingrid Markussen, "Læreruddannelsens første tid - 1791 til ca. 1830", in Karen Braad et al., - for at blive en god loerer: Seminarier $i$ to århundreder (Odense: Odense Universitetsforlag, 2005), 17-130.

54 C. Larsen et al. (2013), 101-7. 


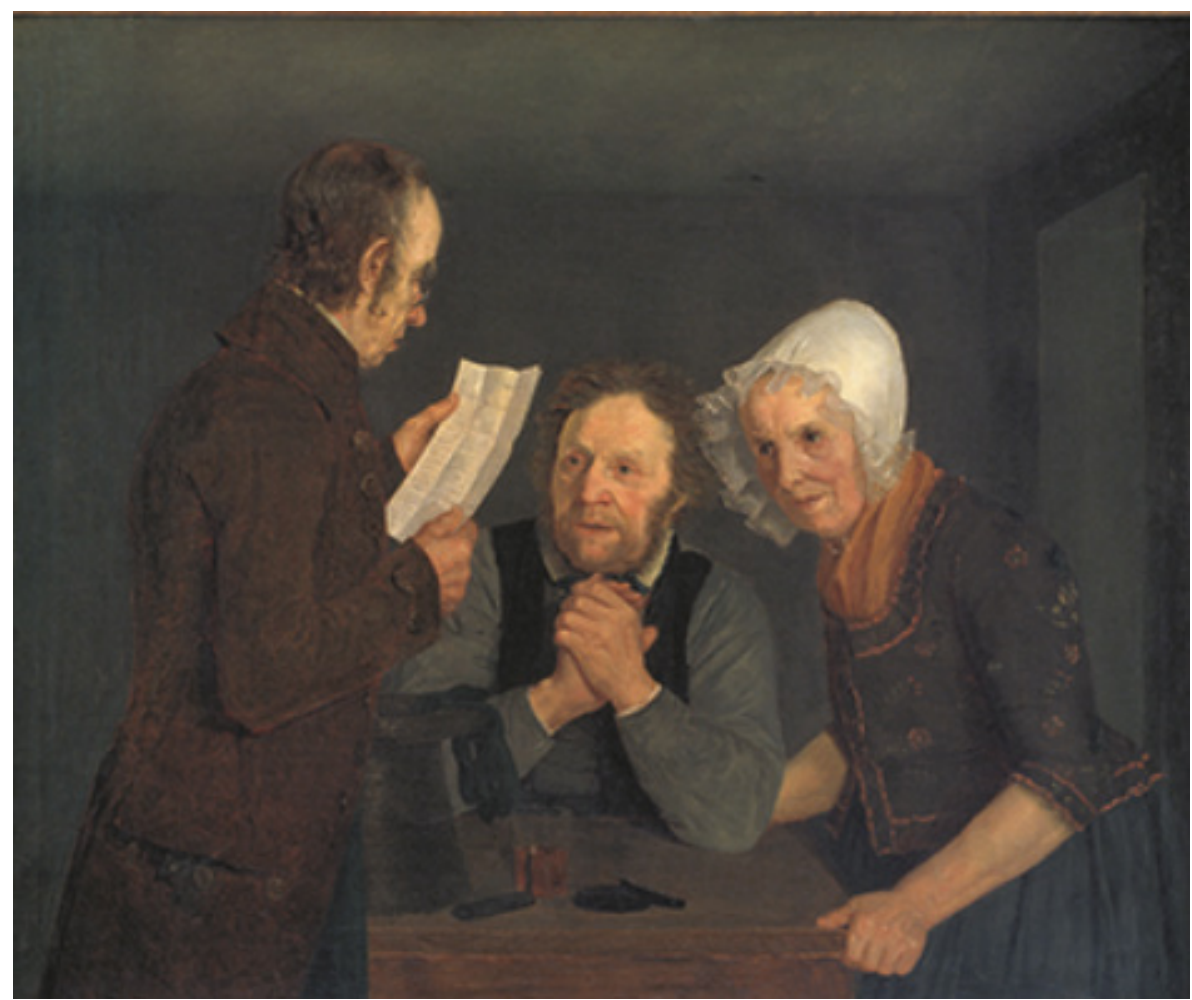

Figure 6. In addition to teaching, the teacher assisted the local community with applications and letters as seen in this picture by Moritz Unna: "A schoolmaster reads to a old couple a letter from their son abroad." Source: Statens Museum for Kunst, Moritz Unna, "En skolemester forelæser et par gamle folk et brev fra deres søn i udlandet" (1835), Copenhagen.

but also to act as a people's teacher (folkeloerer) by communicating his knowledge for the benefit of the residents of the school district. ${ }^{55}$

In the beginning, the seminary educated teachers (seminarister) were the objects of criticism. The clergy worried that the new teachers were not sufficiently humble and that they would be truculent and self-important towards their superior, the pastor. In addition, the new teachers and their more theoretical and pedagogic backgrounds became a target for those who feared that too much education would lead to dissatisfaction and social unrest. ${ }^{56}$

Seminaries not only equipped young men with new knowledge and pedagogic methodology. They also gave them a shared identity, education and formed friendships and social networks. There were, however, still great differences within the teaching profession, regarding pay, ${ }^{57}$ social status and culture between rural schools,

55 Christian Larsen, “Nedlæggelser og stilstand. Læreruddannelsen ca. 1820 til 1860," in Karen Braad et al., - for at blive en god loerer: Seminarier $i$ to århundreder (Odense: Odense Universitetsforlag, 2005), 133-36.

56 C. Larsen et al. (2013), 99-101.

57 J. Larsen (1898), 81; Nørr (1981), 98-106, for rural teachers' salaries; for teachers' salaries in the Duchies see Claus-Hinrich Offen, "Zur wirtschaftlichen Situation der schleswig-holsteinischen Volksschullehrer in der ersten Hälfte des 19. Jahrhunderts”, in Franklin Kopitzsch (hersg.), Erziehungs- und Bildungsgeschichte Schleswig-Holsteins von der Aufklärung bis zum Kaiserreich (Neumünster: Wachholtz, 1981), 115-47. 
those in market towns and the schools and private schools in the cities. There was also a legion of teachers' wives, mothers and female teachers, not covered by the laws, but who made up a large part of the collective teaching profession.

Table 2. Teachers at rural and market towns schools, 1836

\begin{tabular}{l|ccccc} 
Diocese of & $\begin{array}{l}\text { Number of } \\
\text { rural teachers } \\
\text { positions }\end{array}$ & $\begin{array}{l}\text { Newly created } \\
\text { rural teacher } \\
\text { positions }\end{array}$ & $\begin{array}{l}\text { Teachers } \\
\text { educated at a } \\
\text { teacher trai- } \\
\text { ning college }\end{array}$ & $\begin{array}{l}\text { Number of } \\
\text { teachers in } \\
\text { market towns }\end{array}$ & $\begin{array}{l}\text { Teachers in } \\
\text { market towns } \\
\text { with no for- } \\
\text { mal education }\end{array}$ \\
\hline $\begin{array}{l}\text { Zealand } \\
\text { Lolland and }\end{array}$ & 587 & 83 & $80 \%$ & 58 & $14 \%$ \\
$\begin{array}{l}\text { Falster } \\
\text { Funen }\end{array}$ & 244 & 32 & $87 \%$ & 37 & $14 \%$ \\
$\begin{array}{l}\text { Aalborg } \\
\text { (northern part } \\
\text { of Jutland) }\end{array}$ & 275 & 16 & $92 \%$ & 15 & $7 \%$ \\
$\begin{array}{l}\text { Viborg (cen- } \\
\text { tral part of }\end{array}$ & 250 & 41 & $43 \%$ & 18 & $28 \%$ \\
$\begin{array}{l}\text { Jutland } \\
\begin{array}{l}\text { Aarhus (eas- } \\
\text { tern part of }\end{array}\end{array}$ & 423 & 47 & $40 \%$ & 6 & $17 \%$ \\
Jutland) & & 73 & $61 \%$ & 30 & $20 \%$ \\
$\begin{array}{l}\text { Ribe (western } \\
\text { part of Jut- } \\
\text { land) }\end{array}$ & 438 & 53 & $43 \%$ & 26 & $8 \%$ \\
\hline & 2,350 & 345 & $62 \%$ & 190 & $15 \%$
\end{tabular}

Source: "Most humble report on the state of the schools in Denmark, except Copenhagen," October 20, 1837, The Danish Chancellery, 1 Department. H54-2, Various school reports, Various reports concerning public schools, 1805-37, The Danish National Archives, Copenhagen.

Since 1790, the old parish clerk offices had been replaced with college-educated teachers. However, these offices could only be abolished as the local clerks passed away. Almost three decades passed before the last of them died. In the aftermath of the state bankruptcy of 1813 , it was somewhat difficult to attract college-educated teachers for poorly paid offices in Jutland, for example. Many of the new teachers would rather be tutors in private homes in market towns or at an estate where the pay was better and where the teacher did not have to live among peasants..$^{58} \mathrm{~A}$ report from 1836 showed that 40 per cent of all teachers did not have a formal education; it was especially the case in great parts of Jutland (Table 2). ${ }^{59}$ In 1850, 20 per cent of rural teachers were still lacking a formal education. ${ }^{60}$

58 C. Larsen et al. (2013), 312-13.

59 "Most humble report on the state of the schools in Denmark, except Copenhagen," October 20, 1837, The Danish Chancellery, 1 Department. H54-2, Various school reports, Various reports concerning public schools, 1805-37, The Danish National Archives, Copenhagen.

60 "Overview of schools and teachers in the countryside and in the market towns in 1850, extracted from school reports," The Danish Chancellery, 1 Department, H54-3, Various school reports, Teacher training colleges and school statistics, 1789-1857, The Danish National Archives, Copenhagen. 
Many new teachers made their mark on local society. Often, they were the only members of the community with a literary education, alongside the pastor. It had been a vision of the reformers that the teacher, in conjunction with the pastor, should be an educator of the population and an edifying force, a "people's teacher" (folkeloerer) as mentioned above. Many teachers were active in local culture and the local church and many early local libraries were housed in the teacher's home. ${ }^{61}$ Their higher level of education, in comparison to other parishioners, and the contact they maintained through mutual societies and journals prompted some teachers to demand better conditions.

In most schools, the education depended on one single teacher. Therefore, the establishment of a formal teacher training and many new teachers, in conjunction with permanent schoolhouses, played a significant role in educating children in the rural districts, and towns of Denmark. However, the formal teacher training did not create a teacher profession, and great differences still existed

\section{Conclusion: The Emergence of Mass Schooling in Denmark}

In the eighteenth and nineteenth century, schools for the European masses were established: "almueskoler" in Denmark, "folkskoler" in Sweden, "Volksschulen" in the German speaking countries and common schools in the English speaking countries. The majority of school systems had their origin in the seventeenth and eighteenth century with home education, locally founded schools and church schools. During the nineteenth century, one sees the emergence of mass education within a national school system. Prussia had already passed its famous School Act in 1763, Denmark in 1814 and Norway in 1827 but it was especially in the period 1840-1880 that national school systems emerged; for example Sweden and Belgium 1842, Spain 1857, Finland 1866, the Habsburg Empire 1868-69, Britain 1870 and France $1882 .{ }^{62}$

In this article, I have presented the different prerequisites behind the 1814 School Acts and analysed the implementation of the acts. Three aspects are analysed in order to explain the origin of the emergence of Danish mass education in the nineteenth century and to portray the Danish elementary school system; 1) how a local school administration was built, 2) how new school buildings were built, and 3) how a new form of teacher and a new teachers' education was established.

The whole organisation of schooling and schools passed partially into the hands of a fresh administrative structure with local school boards consisting of representatives of (the social superior part of) the rural population in the school district as in Sweden. The involvement of the local population seems to have made a difference for both the development of the local school and its legitimacy and connection to the community. One of the key tasks for newly established school boards was the making of a plan for each parish's public schools. Planning was compulsory but its form varied. This resulted in each parish gaining its own school plan and thus contributing to the large regional and local variances. Another key task for the school boards was making sure that children went to school on a regular basis. However, regular

\footnotetext{
61 Helge Nielsen, Folkebibliotekernes forgangere: Oplysning, almue- og borgerbiblioteker fra 1770erne til 1834 (Copenhagen: Dansk Bibliografisk Kontor, 1960), 210-22.

62 Christelle Garrouste, 100 Years of Educational Reforms in Europe: A contextual database (Luxembourg: EU, 2010), 4; Westberg (2014), 20.
} 
schooling was met with opposition from parents and masters prioritising children's and domestics' work more than frequent schooling. School absences remained a nationwide problem throughout the nineteenth century.

Another main task for the school boards was providing the parish or market town with one or more schoolhouses. Even in the difficult economic times following state bankruptcy in 1813, the government prioritised permanent schoolhouses, and in the following decades the vast majority of schools were established in their own buildings. The government issued guidelines on how to construct a good school building and as a result, schoolhouses all over the country began to resemble each other. However, there were still a variety of local variations; school buildings were not only a question of economy but also dependent on local building traditions, the lord of the local estate and the number of pupils. The negotiations over the layout of a school building, exterior as well as interior, is central to the understanding of how the phenomenon of schools was understood by the main players, both centrally and in the local communities.

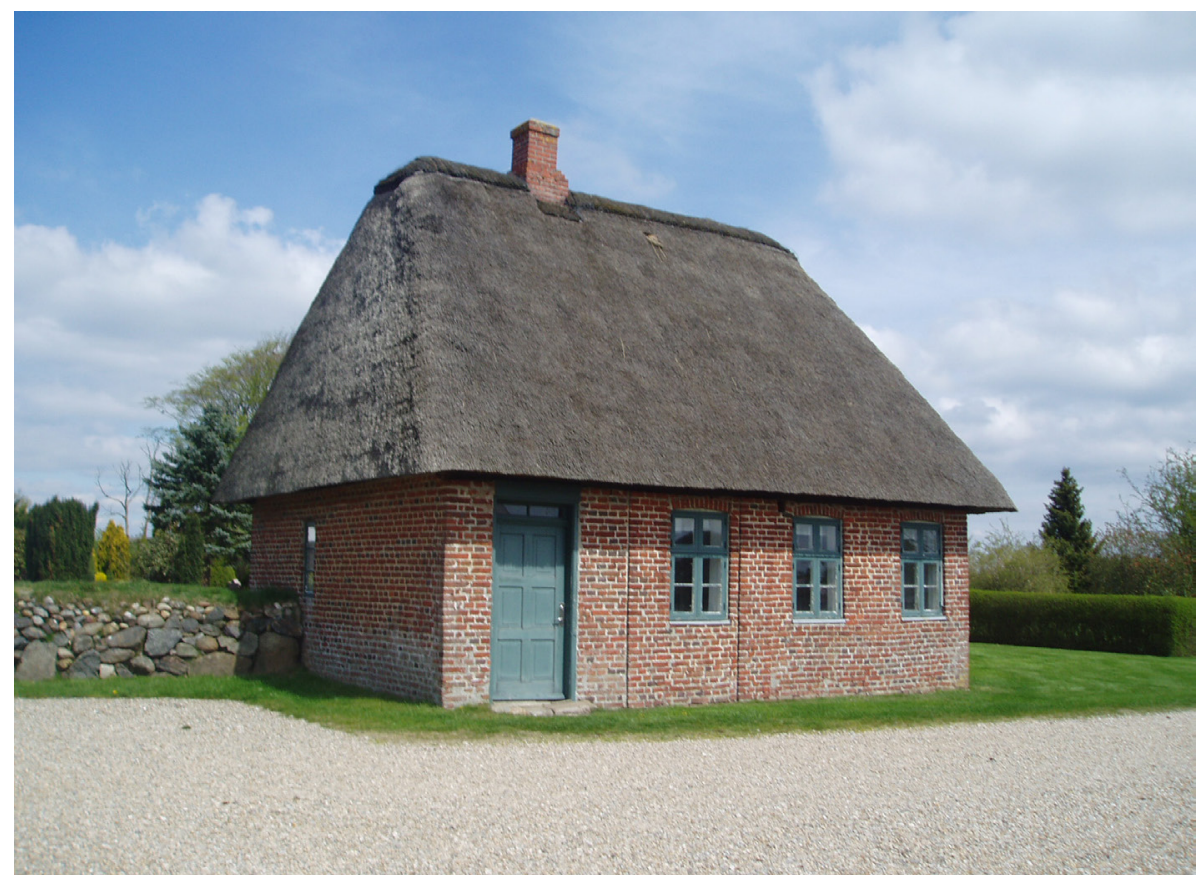

Figure 7. In the years following 1814, many schools were built throughout the Danish realms. Most of them were bricks buildings with thatch like the 1831 school in Hodde in the western part of Jutland. Having gone to the thatched school was a term that lasted until the mid-twentieth century. Source: Photo by Erik Nørr 2010.

The establishment of teachers' training was seen as paramount if schools were to change and the School Acts were to be implemented in all parts of the Danish kingdom, with the majority of schools dependent on one single teacher and his teaching. The establishment of formal training, from the 1780 s onwards, changed the role of teachers. Professional pedagogues taught a new generation of teachers how to teach children according to the regulations in the School Acts and to pedagogic meth- 
odology. They were given a shared identity as members of a group with the task of educating enlightened children and future citizens. However, great differences still existed between teachers in market towns and those in rural and private schools. Therefore, the reformers envisioned that the teacher, in conjunction with the pastor, would be an educator of the population. However, this was not enacted in every place, even though many teachers were active in local culture and the local church, and many early local libraries were housed in the teacher's home.

Scholars have put forward different theories on the emergence of mass schooling in the Western world. ${ }^{63}$ Some have argued that schooling was a way of controlling and disciplining the new working class in a period of great change. ${ }^{64}$ Others have stressed the need of the industrialised society for individuals with knowledge and skills, or have placed the school as a central feature of the emerging nation-state. ${ }^{65}$ Margaret S. Archer sees the emergence of new educational systems as a fight between those who own and thereby control the educational system ("domination"), and those who challenge the domination group ("assertion"). ${ }^{66}$ Andy Green stresses that the development of public education can only be understood in relation to the new nation-state's creation of ideologies and collective beliefs; a national identity, a common language and a single culture. ${ }^{67}$ In the past decades, scholars' attentions have been directed to the local community as the primary force in the emergence of mass schooling. In Peter Lindert's theses on decentralisation it was not the state but the local communities who determined the development of the school; the communities raised taxes for schools, and locally elected and appointed official ran the schools. One could speak of a decentralised school system. ${ }^{68}$

In Denmark, the emergence of mass education took place in a pre-industrial era as in Sweden, Prussia and Norway. ${ }^{69}$ The school system was not intended to discipline a growing working class as the Danish industrialisation took place after 1850 , or to give the industrialised states' inhabitants new skills. From 1780 to 1850, the majority of Danes lived in the countryside and attended the local public school. This meant the vast majority of the male pupils became farmers or day labourers, whilst the girls became wives or servants. In this period, Denmark was not a nation-state but consisted of different realms and colonies. Therefore, five Acts were required in 1814 to cover the Danish king's kingdom and duchies with their varied populations.

63 For an introduction see Nancy Beadie, "Education, social capital and state formation in comparative historical perspective: preliminary investigations," Paedagogica Historica 46, nos. 1-2 (2010), 15-32 and Westberg (2014), 23-28, 290-292.

64 E.P. Thompson, “Time, Work-Discipline, and Industrial Capitalism,” Past \& Present 38 (Dec., 1967), 56-97; Bengt Sandin, Hemmet, gatan, fabriken eller skolan: Folkundervisning och barnuppfostran $i$ svenska städer 1600-1850 (Lund: Arkiv förlag, 1986), 262-265.

65 John Boli, New Citizens For A New Society: The Institutional Origins of Mass Schooling in Sweden (Oxford: Pergamon Press, 1989), 220-248. John W. Meyer, Francisco O. Ramirez, Yasemin Nuhoglu Soysal, "World Expansion of Mass Education, 1870-1980," Sociology of Education 62 (1992), 128 149.

66 Margaret Archer, The Social Origins of Educational Systems (Beverly Hills: Sage, 1979), 90-126.

67 Andy Green, Education and State Formation: The Rise of Educational Systems in England, France and the USA (New York: St Martin's Press, 1990), 77-80.

68 Peter H. Lindert, Growing Public: Volume 1, The Story (Cambridge: Cambridge University Press, 2004), 25. See also Beadie (2010), 30.

69 Westberg (2014), 295-296. 
Mass education in Denmark emerged under the influence of diversity and struggle. It was not a linear process pointing towards the school system known by those historians who, in the late nineteenth and early twentieth century, portrayed the birth of a singular Danish school system. Nor was it a project implemented by a strong, centralistic government with the authority and powers to ensure the fulfilment of every detail of the Acts. In contrast, the emergence was a project formulated by the government but executed at local level by local authorities during a long period. On one hand, the Danish government tried to take overall responsibility for the school by enacting the same regulations for all rural district schools, whether located in villages with large farms or in small fishing villages. Every child had to go to school, and according to the Acts children were supposed to learn the same things in order to be good Christians and loyal subjects, the same being the case for children attending market town schools. Thereby, the government promoted uniformity in the educational field to ensure both the implementation of the Acts and the uniformity within the state.

On the other hand, the government had to accept a diversity of schools. Since the Poor Act of 1708 allowed free education for the children of poor parents, the responsibility for schools had been in local hands. The state issued regulations on a national level, the local community implementing these and financing the schools. Although a stronger state emerged in this period, it could not control everyday life in the many schools outside the capital of Copenhagen. Prior to 1814 there were many local schools organised by the parishioners, the landowner or the church. The government knew that this had led to a variety of school systems due to their origins and the local conditions. As the local conditions were quite different, five Acts were required to fulfil the government's wish to regulate this variety and create a sort of uniformity in the educational field. These differences reflected "variations in the normative condition and practice of schooling prior to state intervention," 70 as noticed by Nancy Beadie on the early period of US schooling. Governments chose different kinds of strategies "more likely to work or be accepted" in a local context. ${ }^{71}$ In Denmark, the government chose five sets of Acts that worked in a local context to secure regular school attendance for the vast majority of children.

In conclusion, the Acts of 1814 and their inherent regulations were imposed from above and from the centre: the absolutist government formed and promulgated the laws, whilst implemented by the central administration. Simultaneously, the schools were run and financed from below: the people and minor officials in individual provostries, parishes and counties had to find the funding themselves for the running of local schools, to find suitable teachers and buildings, as well as books. Much was controlled from the centre and there was not always a free choice in the matter. Sometimes decisions taken locally gave too much flexibility and therefore necessitated a change of rules from the centre. Therefore, schools received a framework from the government that had to be filled locally in a decentralised school system. It was not least here that many and varied parties left their mark from the provost and pastor to the parish clerk, teacher and parents at each school. In this way, the overall picture of schools in the country was a colourful tapestry. In reality, with the local school plans, there were nearly as many School Acts as there were schools.

70 Beadie (2010), 19.

71 Beadie (2010), 19. 


\section{References}

\section{Archival references}

The Danish National Archives, Copenhagen (Rigsarkivet, København)

The Danish Chancellery, 1st Department (Danske Kancellis 1. Departement):

H18. Case no. 1829/1864.

H54-2. Various school reports. Various reports concerning public schools, 18051837.

H54-3. Various school reports. Teacher training colleges and school statistics, 1789-1857.

\section{Printed sources}

Det Statistiske Bureau. Om Almueskolevesenet paa Landet i Danmark i 1857. Statistiske Meddelelser 1. række, 5. bind, 3. hæfte. Copenhagen: Det Statistiske Bureau, 1859.

\section{Website}

Danmarkshistorien.dk. "Det Jødiske Frihedsbrev." Danmarkshistorie.dk, Aarhus Universitet. http://danmarkshistorien.dk/leksikon-og-kilder/vis/materiale/detjoediske-frihedsbrev-af-29-marts-1814 (accessed January 23, 2017).

\section{Literature}

Appel, Charlotte, and Morten Fink-Jensen. Da loereren holdt skole: Tiden før 1780. Aarhus: Aarhus Universitetsforlag, 2013.

Archer, Margaret. The Social Origins of Educational Systems. Beverly Hills: Sage, 1979.

Beadie, Nancy. "Education, social capital and state formation in comparative historical perspective: preliminary investigations.” Paedagogica Historica 46, nos. 1-2 (2010), 15-32.

Bjørn, Claus. Fra reaktion til grundlov 1800-1850: Gyldendal og Politikens Danmarkshistorie, 9. Copenhagen: Gyldendal \& Politikens Forlag, 1986/2002.

Boli, John. New Citizens For A New Society: The Institutional Origins of Mass Schooling in Sweden. Oxford: Pergamon Press, 1989.

Clemmensen, Niels. Konflikt og konsensus: Det landkommunale selvstyre i Danmark $i$ det 19. århundrede. Copenhagen: Museum Tusculanums Forlag, 2011.

Damsholt, Tine. Fodrelandskorlighed og borgerdyd: Patriotisk diskurs og militore reformer i Danmark i det sene 1700-tal. Copenhagen: Museum Tusculanum, 2000.

Den Reventlowske Skole i 150 Aar: Skoleliv ved Brahetrolleborg. Svendborg: Svendborg Amts historiske Samfund, 1933.

Depaepe, Marc, and Frank Simon. "Is there any Place for 'Education' in the 'History of Education'? A Plea for the History of Everyday Educational Reality in- and outside Schools." Paedagogica Historica 31 (1995), 9-16.

Depaepe, Marc. "The Ten Commandments of Good Practices in History of Education Research." In Marc Depaepe, Between Educationalization and Appropriation (Leuven: Leuven University Press, 2012), 463-70.

Engelhardt, Juliane. Borgerskab og follesskab: De patriotiske selskaber $i$ den danske helstat 1769-1814. Copenhagen: Museum Tusculanum, 2010. 
Erichsen, Ernst, and Hermann Sellschopp, eds. Die allgemeine Schulordnung für die Herzogtümer Schleswig und Holstein vom 24. August 1814. Kiel: Ferdinand Hirt, 1964.

Feldbæk, Ole. Danmarks økonomiske historie 1500-1840. Herning: Systime, 1989.

Feldbæk, Ole. Den lange fred 1700-1800: Gyldendal og Politikens Danmarkshistorie, 9. Copenhagen: Gyldendal \& Politikens Forlag, 1986/2002.

Garrouste, Christelle. 100 Years of Educational Reforms in Europe: A contextual database. Luxembourg: EU, 2010.

Glenthøj, Rasmus. Folles kultur - forskellige nationaliteter: De borgerlige eliters skabelse af en national identitet i Danmark og Norge 1807-30. PhD diss., University of Southern Denmark, 2010.

Green, Andy. Education and State Formation: The Rise of Educational Systems in England, France and the USA. New York: St Martin's Press, 1990.

Grue-Sørensen, K. Opdragelsens historie. Copenhagen: Gyldendals pædagogiske bibliotek, 1956-59.

Haue, Harry et al. Skolen i Danmark fra 1500-tallet til i dag. Aarhus: Systime, 1986.

Jessen, Johs. C. Vester og Øster Flakkebjerg Herreds Skolehistorie. Copenhagen: ASAs Forlag, 1938.

Kampmann, Tage et al. Et folk kom i skole 1814-1989. Copenhagen: Institut for Dansk Skolehistorie, 1989.

Knoop, Karl. Zur Geschichte der Lehrerbildung in Schleswig-Holstein: 200 Jahre Lehrerbildung vom Seminar bis zur Pädagogischen Hochschule, 1781-1981. Husum: Husum Druck- und Verlagsgesellschaft, 1984.

Knudsen, Tim. Fra enevelde til folkestyre: Dansk demokratihistorie indtil 1973, 2nd edition. Copenhagen: Akademisk, 2007.

Kopitzsch, Franklin. "Anfänge der Lehrerausbildung im Zeitalter der Aufklärung in Schleswig-Holstein, Hamburg und Lübeck." IZEBF: Information zur Erziehungsund Bildungshistorischen Forschung (1983), 43-64.

Kyrre, Hans. Vor Skole, dens Liv og Love. Copenhagen: Gjellerup, 1933.

Larsen, Christian, Erik Nørr, and Pernille Sonne. Da skolen tog form: 1780-1850. Aarhus: Aarhus Universitetsforlag, 2013.

Larsen, Christian. "Nedlæggelser og stilstand: Læreruddannelsen ca. 1820 til 1860." In Karen Braad et al., - for at blive en god loerer: Seminarier $i$ to århundreder, 129-78. Odense: Odense Universitetsforlag, 2005.

Larsen, Christian. "Skolen for livet: Realskolen i debat og lovgivning 1814-1923." In Realskolen gennem 200 år - kundskaber og erhvervsforberedelse, edited by Christian Larsen, 79-136. Copenhagen: Danmarks Privatskoleforening, 2010.

Larsen, Joakim, ed. Skolelovene af 1814 og deres Tilblivelse, aktmoessigt fremstillet, udgivet i Hundredaaret for Anordningernes Udstedelse. Copenhagen: J.H. Schultz, 1914.

Larsen, Joakim. Bidrag til den danske Folkeskoles Historie 1784-1818. Copenhagen: V. Thaning \& Appel, 1893 (reprinted 1984).

Larsen, Joakim. Bidrag til den danske Folkeskoles Historie 1818-1898. Copenhagen: Det Schoubotheske Forlag, 1898 (reprinted 1984).

Lindert, Peter H. Growing Public: Volume 1, The Story. Cambridge: Cambridge University Press, 2004. 
Løgstrup, Birgit. Bondens frigørelse: De danske landboreformer 1750-1810. Copenhagen: Gad, 2015.

Markussen, Ingrid. "Læreruddannelsens første tid: 1791 til ca. 1830." In Karen Braad et al., - for at blive en god loerer: Seminarier $i$ to århundreder, 17-130. Odense: Odense Universitetsforlag, 2005.

Markussen, Ingrid. Til skaberens ore, statens tjeneste og vor egen nytte: Pietistiske og kameralistiske idéer bag fremvoksten af en offentlig skole i landdistrikterne $i$ 1700-tallet. Odense: Odense Universitetsforlag, 1995.

Markussen, Ingrid. Visdommens loenke: Studier i enevoldens skolereformer fra Reventlow til skolelov. Odense: Landbohistorisk Selskab, 1988.

Meyer, John W., Francisco O. Ramirez, Yasemin Nuhoglu Soysal. "World Expansion of Mass Education, 1870-1980.” Sociology of Education 65 (1992), 128-149.

Mintz, Steve. Huck's Raft: A History of American Childhood. Cambridge: Harvard University Press, 2004.

Nellemann, Aksel H. Den danske skoles historie. Copenhagen: Gjellerup, 1966.

Nielsen, Helge. Folkebibliotekernes forgangere: Oplysning, almue- og borgerbiblioteker fra 1770erne til 1834. Copenhagen: Dansk Bibliografisk Kontor, 1960.

Nørr, Erik. Pfarrer und Administrator: Die Funktionen des Gemeindepfarrers in der ländlichen Lokalverwaltung 1800-1841. Copenhagen: Rigsarkivet, 1984.

Nørr, Erik. Proest og administrator: Sogneprostens funktioner i lokalforvaltningen på landet fra 1800 til 1841. Copenhagen: Rigsarkivet, 1981.

Nørr, Erik. Skolen, proesten og kommunen: Kampen om skolen på landet 1842-1899. Copenhagen: Jurist- og Økonomforbundet, 1994.

Offen, Claus-Hinrich. "Zur wirtschaftlichen Situation der schleswig-holsteinischen Volksschullehrer in der ersten Hälfte des 19. Jahrhunderts." In Erziehungs- und Bildungsgeschichte Schleswig-Holsteins von der Aufklärung bis zum Kaiserreich, edited by Franklin Kopitzsch, 115-47. Neumünster: Wachholtz, 1981.

Olsen, Olaf, ed. Gyldendal og Politikens Danmarkshistorie. Copenhagen: Gyldendal \& Politikens Forlag, 1986-1992, 2nd ed., 2002-2005.

Reeh, Niels. Religion and the state of Denmark: State religious politics in the elementary school system from 1721 to 1975, Ph.D. diss., Copenhagen University, 2006.

Reeh, Niels. Secularization Revisited: Teaching Religion and the State of Denmark 1721 to 2006. New York: Springer, 2016.

Sandin, Bengt. Hemmet, gatan, fabriken eller skolan: Folkundervisning och barnuppfostran i svenska städer 1600-1850. Lund: Arkiv förlag, 1986.

Schmidt, J. Boisen. Til duelige skoleholderes dannelse: Jonstrup Statsseminarium 1790-1990. Lyngby: Jonstrups Venner, 1992.

Sonne, Pernille. "Kampen om børnenes tid : Hensynet til arbejdslivet i Almueskoleloven af 1814." Kirkehistoriske Samlinger (2015), 165-74.

Stargardt, Nicholas. Witnesses of War: Children's Lives under the Nazis. London: Jonathan Cape, 2005.

Thompson E. P. “Time, Work-Discipline, and Industrial Capitalism.” Past \& Present 38 (Dec., 1967), 56-97.

Westberg, Johannes. Att bygga ett skolväsende: Folkskolans förutsättningar och framväxt 1840-1900. Lund: Nordic Academic Press, 2014. 